\title{
Disease spectrum and treatment patterns in a local male infertility clinic
}

\author{
KL Ho *, James HL Tsu, PC Tam, MK Yiu
}

\section{A B S T R A C T}

Objective: To review disease spectrum and treatment patterns in a local male infertility clinic.

Design: Case series.

Setting: Male infertility clinic in a teaching hospital in Hong Kong.

Patients: Patients who were seen as new cases in a local male infertility clinic between January 2008 and December 2012.

Intervention: Infertility assessment and counselling on treatment options.

Main outcome measures: Disease spectrum and treatment patterns.

Results: A total of 387 new patients were assessed in the male infertility clinic. The mean age of the patients and their female partners was 37.2 and 32.1 years, respectively. The median duration of infertility was 3 years. Among the patients, 36.2\% had azoospermia, $8.0 \%$ had congenital absence of vas deferens, and $48.3 \%$ of patients had other abnormalities in semen parameters. The commonest causes of male infertility were unknown (idiopathic), clinically significant varicoceles, congenital absence ejaculatory dysfunction. Overall, $66.1 \%$ of patients chose assisted reproductive treatment and $12.4 \%$ of patients preferred surgical correction of reversible male infertility conditions. Altogether $36.7 \%$ of patients required either surgical sperm retrieval or correction of male infertility conditions.

Conclusions: The present study provided important local data on the disease spectrum and treatment patterns in a male infertility clinic. The incidences of azoospermia and congenital absence of vas deferens were much higher than those reported in the contemporary literature. A significant proportion of patients required either surgical sperm retrieval or correction of reversible male infertility conditions.
Hong Kong Med J 2015;21:5-9
DOI: 10.12809/hkmj144376
KL Ho *, FRCSEd (Urol), FHKAM (Surgery)
JHL Tsu, FRCSEd (Urol), FHKAM (Surgery)
PC Tam, FRCSEd (Urol), FHKAM (Surgery)
MK Yiu, FRCS (Edin), FHKAM (Surgery)
Division of Urology, Department of Surgery, The University of Hong Kong, Queen Mary Hospital, Pokfulam, Hong Kong
* Corresponding author: hokwanlun@gmail.com

New knowledge added by this stud

- The present study provided important local data on the disease spectrum and treatment patterns in a male infertility clinic.

- The incidences of azoospermia and congenital absence of vas deferens in the present study were much higher than those reported in the contemporary literature.

Implications for clinical practice or policy

- The present study may help to increase public awareness of the contribution of male factors in infertility assessment and treatment.

- The study provides a background for future research into azoospermia and congenital absence of vas deferens in the locality.

\section{Introduction}

Infertility is defined by the inability to conceive after 1 year of regular unprotected sexual intercourse, and it affects $15 \%$ of couples worldwide. ${ }^{1}$ Male factors contribute to about $50 \%$ of infertile couples. Clinically significant varicocele is present in $40 \%$ of infertile men and is the commonest surgically reversible condition. As many as $10 \%$ to $15 \%$ of infertile men have azoospermia. ${ }^{2}$ According to the report of the Council on Human Reproductive Technology in 2012, male factor infertility contributes to $50 \%$ of women receiving reproductive technology treatment. ${ }^{3}$ Local data on male factor infertility, however, have been scarce. The objective of the present article was to review the disease spectrum and treatment patterns in a local male infertility clinic.

\section{Methods}

All consecutive new patients seen in a local teaching hospital (Queen Mary Hospital) male infertility clinic from January 2008 to December 2012 were included in this retrospective study. The clinical 


\section{在本地一所男性不育診所中的疾病譜和治療模式} 何崑崙、徐學良、談寶雛、姚銘廣

目的：回顧本地一所男性不育診所中的疾病譜和治療模式。

設計：病例系列研究。

安排：香港一所教學醫院內的男性不育診所。

患者：2008年1月至2012年12月期間到上述診所的新症患者。

干預：不育檢查以及治療方案的諮詢。

主要結果測量 : 疾病譜和治療模式。

結果：共387名新症患者接受評估。患者和其女性伴侶的平均年齡分 別為 37.2 及 32.1 歲。不育的中位年期為3年。患者中有 $36.2 \%$ 被診斷為 無精子症、 $8.0 \%$ 為先天性無輸精管和 $48.3 \%$ 其精液參數出現異常。男 性不育的常見原因為不明（特發性）、臨床顯著的精索靜脈曲張、先 天性無輸精管、青春期後的腮腺炎, 以及勃起或射精功能障礙。總體 來説, $66.1 \%$ 的患者選擇輔助生殖治療, $12.4 \%$ 選擇進行手術矯正以改 變可逆性男性不育的情況。患者中共有 $36.7 \%$ 須進行手術取精或手術 矯正。

結論：本研究提供了本地一所男性不育診所中的疾病譜和治療模式的 重要數據。無精症和先天性無輸精管的現患率明顯遠高於現今文獻中 的數據。有相當比例的患者須進行手術取精或手術矯正以改變可逆性 男性不育的情況。 significant in the assessment. Diagnosis of congenital absence of vas deferens was made by physical examination and occasionally supplemented with transrectal ultrasound for unclear cases. For patients with a history of mumps after puberty and no other identifiable causes of male infertility, mumps was quoted as the main cause. Depending on the clinical scenarios, the couples were counselled on different treatment options, including surgical or assisted reproductive treatments (ART), donor insemination, adoption, and conservative treatment.

\section{Results}

From January 2008 to December 2012, 387 patients had been seen in the male infertility clinic as new cases. The mean age of the patients and their female partners was 37.2 and 32.1 years, respectively. The median duration of infertility was 3 years. Of the patients, 140 (36.2\%) had azoospermia, of whom 67 and 71 patients had obstructive and non-obstructive causes, respectively, and two had both components of azoospermia. A total of 187 (48.3\%) patients had abnormalities in one or more semen parameters (Table 1).

The commonest causes of male factor infertility were unknown (idiopathic), clinically significant varicoceles, congenital absence of vas deferens, mumps after puberty, and erectile or ejaculatory dysfunction (Table 2). For patients with obstructive azoospermia, common pathologies included congenital absence of vas deferens and genital tract infection. For patients with non-obstructive azoospermia, no causes were identified in most patients. A history of mumps and endocrinopathies were implicated in some non-obstructive azoospermic patients (Table 3). history was taken, followed by a focused physical examination. The fertility history was ascertained and female factors of age and gynaecological history were taken into consideration. Clinical diagnoses were made and possible aetiologies were postulated based on the above information. The patients' semen results were classified as azoospermia (no sperms were identified after examination of the postcentrifugation pellet), abnormal (in concentration, motility, morphology, or any combination according to the contemporary World Health Organization standards ${ }^{4}$ ), or normal. The exact analysis of semen parameters was beyond the scope of the present study. Patients with azoospermia were classified clinically as having obstructive (normal-sized testes and hormonal profiles) and non-obstructive (small testes and elevated follicle-stimulating hormones) disorder. Genetic studies, including karyotyping and $\mathrm{Y}$ chromosome microdeletion, were offered to patients with non-obstructive azoospermia or severe oligospermia. Only grade 2 (palpable) or 3 (visible) varicoceles when standing were considered clinically
TABLE I. Demographics and semen parameters of patients attending the male infertility clinic $(n=387)$

\begin{tabular}{lc}
\hline Demographics and semen parameters & Data* \\
\hline Mean (range) age (years) & $37.2(18-71)$ \\
Male partner & $32.1(18-46)$ \\
Female partner & 3 \\
Median duration of infertility (years) & \\
Semen parameters & $140(36.2 \%)$ \\
Azoospermia & 67 \\
$\quad$ Obstructive & 71 \\
$\quad$ Non-obstructive & 2 \\
$\quad$ Both & $187(48.3 \%)$ \\
Abnormalities in any one or more semen & \\
parameters & $44(11.4 \%)$ \\
Normal & $16(4.1 \%)$ \\
\hline
\end{tabular}

* Data are shown as mean (range), No., or No. (\%) 
TABLE 2. Disease spectrum in patients attending the male infertility clinic

\begin{tabular}{|c|c|}
\hline Cause of infertility & No. $(\%)$ of patients \\
\hline Idiopathic & $155(40.0)$ \\
\hline Varicocele & $81(20.9)$ \\
\hline Congenital absence of vas deferens & $31(8.0)$ \\
\hline History of mumps after puberty & $31(8.0)$ \\
\hline Erectile or ejaculatory dysfunction & $27(7.0)$ \\
\hline Erectile dysfunction & 5 \\
\hline Ejaculatory dysfunction & 22 \\
\hline Genital tract infection & $20(5.2)$ \\
\hline Cryptorchidism & $13(3.4)$ \\
\hline Others & $12(3.1)$ \\
\hline Ejaculatory duct obstruction & 2 \\
\hline Vasectomy & 6 \\
\hline Bilateral inguinal hernia surgery & 1 \\
\hline Carcinoma of the testis & 3 \\
\hline Drugs & $7(1.8)$ \\
\hline Chemotherapy & 3 \\
\hline Azathioprine & 1 \\
\hline Finasteride & 1 \\
\hline Methadone & 1 \\
\hline Mesalazine & 1 \\
\hline Endocrinopathies & $10(2.6)$ \\
\hline Kallman syndrome & 3 \\
\hline Idiopathic secondary hypogonadism & 3 \\
\hline Klinefelter syndrome & 4 \\
\hline
\end{tabular}

Most patients $(66.1 \%)$ sought ART. Of these patients, 94 azoospermic patients (56 patients with non-obstructive azoospermia, 37 with obstructive azoospermia, and one with both components) required sperm retrieval procedures. Besides, $12.4 \%$ patients chose surgical treatments for reversible causes of male infertility. The procedures included varicocelectomy, vas reconnection, and vasoepididymostomy. Four patients with varicoceles and severe oligospermia or azoospermia proceeded to varicocelectomy and employed ART as backup treatment. Also, $19.6 \%$ patients elected to have no further treatment of infertility (Table 4).

Of 81 patients who had clinically significant varicoceles and abnormal semen parameters, 23 proceeded to surgery and 38 chose ART. Of 67 patients who had obstructive azoospermia, 37 proceeded to ART; 28 of these patients had congenital absence of vas deferens that was irreversible, requiring sperm retrieval and ART. For the other patients with reversible causes of obstructive azoospermia, nine preferred sperm retrieval and ART, while 25 elected to have surgical treatments (Table 5).
TABLE 3. Common pathologies of azoospermic patients

\begin{tabular}{|cc|}
\hline Type of azoospermia & No. of patients \\
\hline Obstructive & 67 \\
\hline Congenital absence of vas deferens & 31 \\
\hline Genital tract infection & 16 \\
\hline Idiopathic & 11 \\
\hline Vasectomy & 6 \\
\hline Ejaculatory duct obstruction & 2 \\
\hline Bilateral inguinal hernia surgery & 1 \\
\hline Non-obstructive & 71 \\
\hline Idiopathic & 40 \\
\hline History of mumps & 12 \\
\hline Endocrinopathies & 8 \\
\hline Varicocele & 5 \\
\hline Cryptorchidism & 4 \\
\hline Drugs & 2 \\
\hline
\end{tabular}

TABLE 4. Treatment patterns of the male infertility clinic

\begin{tabular}{|cc|}
\hline Treatment pattern & No. (\%) of patients \\
\hline Surgical treatment & $48(12.4)$ \\
\hline Varicocelectomy & $23^{\star}$ \\
\hline Vasoepididymostomy & 20 \\
\hline Vas reconnection & 3 \\
\hline TUR-ED & 2 \\
\hline ART & $256(66.1)^{\star} \dagger$ \\
\hline No treatment & $76(19.6)$ \\
\hline Erectile dysfunction treatment & $4(1.0)$ \\
\hline Adoption & $3(0.8)$ \\
\hline
\end{tabular}

Abbreviations: ART = assisted reproductive treatment:

TUR-ED = transurethral resection of ejaculatory duct

* Four patients elected to have both varicocelectomy and ART

+ 94 Azoospermic patients needed sperm retrieval procedures

TABLE 5. Common pathologies and treatment patterns

\begin{tabular}{lc}
\hline $\begin{array}{l}\text { Pathology/treatment } \\
\text { pattern }\end{array}$ & No. of patients \\
\hline Varicocele & 81 \\
\hline ART & 38 \\
\hline Surgery & 19 \\
Surgery + ART & 4 \\
No treatment & 18 \\
\hline Adoption & 2 \\
Obstructive azoospermia & 67 \\
\hline ART & 37 (28 irreversible causes, \\
& 9 reversible causes) \\
Surgery & 25 (reversible causes) \\
No treatment & 5 (3 irreversible causes, \\
& 2 reversible causes) \\
\hline
\end{tabular}

Abbreviation: $A R T$ = assisted reproductive treatment 


\section{Discussion}

Infertility has remained a worldwide problem in the past two decades. ${ }^{5}$ Traditionally, the female partner has shouldered the major burden of infertility assessment and treatment. With recent advances in male infertility treatment ${ }^{6}$ and increasing public awareness, there is a growing demand for assessment and treatment of men with fertility issues.

When the infertility clinic at Queen Mary Hospital was first established, it consisted of a joint clinic assessment both by urologists specialising in male infertility treatment and by gynaecologists specialising in ART. Due to the long waiting list at the conjoint clinic, the male infertility clinic has since separated out. All infertile couples with clinically suspected male infertility factors-such as gross abnormalities in semen parameters, or erectile or ejaculatory dysfunction-are referred to the male infertility clinic for prompt assessment.

The median duration of infertility in this study was 3 years before the infertile couples attended for assessment. Upon referral, a large proportion (36.2\%) of patients had azoospermia. This figure was much higher than the commonly quoted figures in the current literature, where azoospermia was found in $1 \%$ of all men and $10 \%$ to $15 \%$ of infertile men. ${ }^{7-9}$ The much higher figure in the present study was probably related to referral bias. Male partners with milder forms of abnormalities in semen parameters might not have been referred for assessment. These couples with an azoospermic male partner would have benefited from earlier intervention instead of wasting precious time attempting natural conception. The present study illustrates the importance of a premarital, or at least a pre-pregnancy, checkup. Simple semen analysis would have identified male partners with azoospermia or severe deficits of semen parameters for early assessment, fertility treatment, counselling, and potential intervention.

Besides, $11.4 \%$ of patients had normal semen parameters and fell into the category of unexplained infertility. ${ }^{10}$ After common female factors have been ruled out, there are still many possible causes of infertility, ranging from the couple's miscomprehension of the female fertility window and coital behaviours to abnormal sperm function. ${ }^{11}$

Clinically significant varicocele was the commonest identifiable cause of male infertility in the present study. This was concurrent with the contemporary literature. ${ }^{12}$ Controversies over the best treatment of varicoceles in infertile couples have been met with a meta-analysis ${ }^{13}$ and randomised controlled trials ${ }^{14,15}$ favouring surgery in terms of pregnancy outcomes. Varicocelectomy is offered to patients according to the criteria of the American Society for Reproductive Medicine, ${ }^{12}$ namely, documented history of infertility, grade 2 or above varicocele, abnormalities in semen parameters, and reversible female factors. In our institution, the microsurgical subinguinal approach is used for its lower risks of recurrence and hydrocele. ${ }^{16}$ In the present study, 38 patients with varicoceles chose ART, while 23 patients chose surgery. The decision to proceed to ART versus varicocelectomy was made after thorough counselling of the involved couples. Factors considered included the female partner's age, semen quality, risks of surgery versus ART, expertise of the surgeons and ART centre staff, and the respective treatment outcome audits. Both male and female partners were strongly encouraged to attend counselling together and arrive at the decision that is most agreeable to both parties.

A significant proportion of patients in the study had azoospermia, of which $47.9 \%$ had obstructive causes. Congenital absence of vas deferens was the commonest cause of obstructive azoospermia, which constituted $8.0 \%$ of the study population. This was higher than the $1 \%$ to $2 \%$ of infertile men reported in the literature. ${ }^{7,9}$ The incidence of congenital absence of vas deferens is not well reported in Chinese men with infertility. One of the reasons for the high incidence in this study could be referral bias, which led to a very high incidence of azoospermia in our study population. Hence, the proportional percentage of congenital absence of vas deferens was much higher than is usually quoted. Sperm retrieval and ART was offered as the only solutions for childbearing. In Caucasians, congenital absence of vas deferens is associated with cystic fibrosis transmembrane conductance regulator (CFTR) gene mutations of cystic fibrosis, ${ }^{17}$ and routine genetic study is offered to patients and their female partners. Recent data in Chinese patients with congenital absence of vas deferens showed different CFTR gene mutations, ${ }^{18}$ which might lead to the development of a mild genital form of cystic fibrosis. Cystic fibrosis is very rare in Asian populations, but genetic counselling for patients with congenital absence of vas deferens is still advised by most authorities. Unfortunately, genetic study is not available at Queen Mary Hospital, and the huge number of possible CFTR gene mutations ( $>1500)$ makes targeted examination in Chinese patients a big challenge.

Of 256 patients who proceeded to ART, 94 with azoospermia needed some sort of sperm retrieval procedures. For patients with congenital absence of vas deferens and markedly distended epididymal tubules, percutaneous epididymal sperm aspiration provided a simple and reliable method of sperm retrieval. For patients with obstructive azoospermia secondary to infection or idiopathic causes, microsurgical epididymal sperm aspiration was employed to retrieve the maximum number of sperms with the least blood contamination. Sometimes extensive adhesiolysis needed to be 
performed to expose distended epididymal tubules. Non-obstructive azoospermia was the most difficult condition to treat. Conventional testicular sperm extraction (TESE) involves multiple random testis biopsies and can fail to find focal seminiferous tubules harbouring active spermatogenesis. This method involves excision of more testicular tissues and is associated with more postoperative intra-testicular haematoma and scarring. ${ }^{19}$ Microdissection TESE (MicroTESE) involves identifying the spermatogenically active regions of the testes by direct examination of larger seminiferous tubules under high magnification. ${ }^{20}$ This method is targeted and involves retrieval of the maximum number of sperms with the least testicular tissue loss. However, MicroTESE is time-consuming and involves a steep learning curve. ${ }^{21}$ Even in the hands of experts, the procedure takes an average of 1.8 and 2.7 hours for successful and unsuccessful cases, respectively.

Of 36 patients with reversible causes of obstructive azoospermia (Table 5), 25 (69.4\%) chose surgical treatment, nine proceeded to ART, and two preferred conservative treatment. In the era of ART, surgical treatment remains a valuable armamentarium in the management of reversible obstructive azoospermia. ${ }^{1}$ At Queen Mary Hospital, microsurgical intussusception vasoepididymostomy was offered to patients with epididymal obstruction secondary to infection or idiopathic causes. ${ }^{22}$ The choice between surgical treatment and ART was made after thorough consideration of the female partner's age, surgical expertise and ART success rates, and the infertile couple's wishes.

Within this study population, 142 (36.7\%) patients needed either surgical sperm retrieval and ART or surgical correction of reversible male infertility conditions.

\section{Conclusions}

The present study describes the disease spectrum of a local male infertility clinic. The incidence of azoospermia and congenital absence of vas deferens was much higher than that described in the current literature. There was high demand for sperm retrieval or surgical correction services in this group of patients.

\section{References}

1. Lee R, Li PS, Schlegel PN, Goldstein M. Reassessing reconstruction in the management of obstructive azoospermia: reconstruction or sperm acquisition? Urol Clin North Am 2008;35:289-301.

2. Practice Committee of American Society for Reproductive Medicine in collaboration with Society for Male Reproduction and Urology. The management of infertility due to obstructive azoospermia. Fertil Steril 2008;90(5 Suppl):S121-4.

3. Infertility diagnosis by age of patients receiving RT procedures (other than DI and AIH) in 2012. Council on Human Reproductive Technology. Available from: http:// www.chrt.org.hk/english/publications/files/table17_2012. pdf. Accessed Aug 2014.

4. Cooper TG, Noonan E, von Eckardstein S, et al. World Health Organization reference values for human semen characteristics. Hum Reprod Update 2010;16:231-45.

5. Mascarenhas MN, Flaxman SR, Boerma T, Vanderpoel S, Stevens GA. National, regional, and global trends in infertility prevalence since 1990: a systematic analysis of 277 health surveys. PLoS Med 2012;9:e1001356.

6. Male Infertility Best Practice Policy Committee of the American Urological Association; Practice Committee of the American Society for Reproductive Medicine. Report on optimal evaluation of the infertile male. Fertil Steril 2006;86(5 Suppl 1):S202-9.

7. Wosnitzer M, Goldstein M, Hardy MP. Review of azoospermia. Spermatogenesis 2014;4:e28218.

8. Berookhim BM, Schlegel PN. Azoospermia due to spermatogenic failure. Urol Clin North Am 2014;41:97-113.

9. Wosnitzer MS, Goldstein M. Obstructive azoospermia. Urol Clin North Am 2014;41:83-95.

10. Hamada A, Esteves SC, Agarwal A. Unexplained male infertility-looking beyond routine semen analysis. Eur Urol Rev 2012;7:90-6.

11. Agarwal A, Bragais FM, Sabanegh E. Assessing sperm function. Urol Clin North Am 2008;35:157-71, vii.

12. Practice Committee of American Society for Reproductive Medicine. Report on varicocele and infertility. Fertil Steril 2008;90(5 Suppl):S247-9.

13. Marmar JL, Agarwal A, Prabakaran S, et al. Reassessing the value of varicocelectomy as a treatment for male subfertility with a new meta-analysis. Fertil Steril 2007;88:639-48.

14. Abdel-Meguid TA, Al-Sayyad A, Tayib A, Farsi HM. Does varicocele repair improve male infertility? An evidencebased perspective from a randomized, controlled trial. Eur Urol 2011;59:455-61.

15. Mansour Ghanaie M, Asgari SA, Dadrass N, Allahkhah A, Iran-Pour E, Safarinejad MR. Effects of varicocele repair on spontaneous first trimester miscarriage: a randomized clinical trial. Urol J 2012;9:505-13.

16. Leung L, Ho KL, Tam PC, Yiu MK. Subinguinal microsurgical varicocelectomy for male factor subfertility: ten-year experience. Hong Kong Med J 2013;19:334-40.

17. Esteves SC, Miyaoka R, Agarwal A. Sperm retrieval techniques for assisted reproduction. Int Braz $\mathrm{J}$ Urol 2011;37:570-83.

18. Lu S, Yang X, Cui Y, et al. Different cystic fibrosis transmembrane conductance regulator mutations in Chinese men with congenital bilateral absence of vas deferens and other acquired obstructive azoospermia. Urology 2013;82:824-8.

19. Okada H, Dobashi M, Yamazaki T, et al. Conventional versus microdissection testicular sperm extraction for nonobstructive azoospermia. J Urol 2002;168:1063-7.

20. Schlegel PN. Testicular sperm extraction: microdissection improves sperm yield with minimal tissue excision. Hum Reprod 1999;14:131-5.

21. Dabaja AA, Schlegel PN. Microdissection testicular sperm extraction: an update. Asian J Androl 2013;15:35-9.

22. Ho KL, Wong MH, Tam PC. Microsurgical vasoepididymostomy for obstructive azoospermia. Hong Kong Med J 2009;15:452-7. 